Review

\title{
Oncolytic Virotherapy for Cancer: Clinical Experience
}

\author{
Shyambabu Chaurasiya *(1), Yuman Fong and Susanne G. Warner (1) \\ Department of Surgery, City of Hope National Medical Center, Duarte, CA 91010, USA; yfong@coh.org (Y.F.); \\ suwarner@coh.org (S.G.W.) \\ * Correspondence: schaurasiya@coh.org; Tel.: +1-626-218-0060
}

Citation: Chaurasiya, S.; Fong, Y.; Warner, S.G. Oncolytic Virotherapy for Cancer: Clinical Experience. Biomedicines 2021, 9, 419. https:// doi.org/10.3390/biomedicines9040419

Academic Editors: Zong Sheng Guo and David L. Bartlett

Received: 14 March 2021

Accepted: 7 April 2021

Published: 13 April 2021

Publisher's Note: MDPI stays neutral with regard to jurisdictional claims in published maps and institutional affiliations.

Copyright: (c) 2021 by the authors. Licensee MDPI, Basel, Switzerland. This article is an open access article distributed under the terms and conditions of the Creative Commons Attribution (CC BY) license (https:// creativecommons.org/licenses/by/ $4.0 /)$.

\begin{abstract}
Oncolytic viruses are a new class of therapeutics which are largely in the experimental stage, with just one virus approved by the FDA thus far. While the concept of oncolytic virotherapy is not new, advancements in the fields of molecular biology and virology have renewed the interest in using viruses as oncolytic agents. Backed by robust preclinical data, many oncolytic viruses have entered clinical trials. Oncolytic viruses that have completed some levels of clinical trials or are currently undergoing clinical trials are mostly genetically engineered viruses, with the exception of some RNA viruses. Reolysin, an unmodified RNA virus is clinically the most advanced oncolytic RNA virus that has completed different phases of clinical trials. Other oncolytic viruses that have been studied in clinical trials are mostly DNA viruses that belong to one of the three families: herpesviridae, poxviridae or adenoviridae. In this review work we discuss recent clinical studies with oncolytic viruses, especially herpesvirus, poxvirus, adenovirus and reovirus. In summary, the oncolytic viruses tested so far are well tolerated, even in immune-suppressed patients. For most oncolytic viruses, mild and acceptable toxicities are seen at the currently defined highest feasible doses. However, anti-tumor efficacies of oncolytic viruses have been modest, especially when used as monotherapy. Therefore, the potency of oncolytic viruses needs to be enhanced for more oncolytic viruses to hit the clinic. Aiming to achieve higher therapeutic benefits, oncolytic viruses are currently being studied in combination with other therapies. Here we discuss the currently available clinical data on oncolytic viruses, either as monotherapy or in combination with other treatments.
\end{abstract}

Keywords: oncolytic virus; clinical trials; adenovirus; vaccinia virus; herpes virus; reovirus

\section{Introduction}

There has been an increasing interest in using viruses as potential therapeutics for different types of diseases. Two main ways in which viruses are being explored as therapeutics are (1) vectors for gene therapy and (2) oncolytic viruses. While viruses as vector for gene therapy are being studied for a wide range of diseases including cancer, "oncolytic viruses" are specific for cancer treatment. The major difference between viral vector for gene therapy and oncolytic virus is that viral vectors used in gene therapy are non-replicating viruses, whereas oncolytic viruses are replication-competent viruses. Oncolytic viruses (OV) are wild-type or engineered viruses that can selectively replicate in and kill cancer cells while leaving normal cells unharmed. OVs are a novel class of multi-mechanistic therapeutics for the treatment of cancer. Some of the mechanisms through which OVs exert their anti-cancer effect include direct lysis of cancer cells and activation of anti-tumor immunity (Figure 1).

The concept of using viruses to kill cancer is not new, there is anecdotal evidence of anti-tumor benefits from virus infections dating back to a century ago (reviewed in [1,2]). However, the field of oncolytic virus research has only recently gained momentum as a result of recent advancements in molecular biology and virology. In the last two decades, a wide diversity of virus families, including adenoviridae, poxviridae, herpesviridae, rhabdoviridae, reoviridae, paramyxoviridae, parvoviridae and picornaviridae, have been studied for their potential as oncolytic agents (reviewed in [3]). While the majority of them are still in preclinical stage of testing, some of them have completed different phases 
of clinical trials. Specifically, viruses belonging to the families adenoviridae, poxviridae, herpesviridae and reoviridae are the ones that have been studied in clinical settings. In this review article, we discuss the viruses from these four families that have been studied or are being studied in clinical trials.

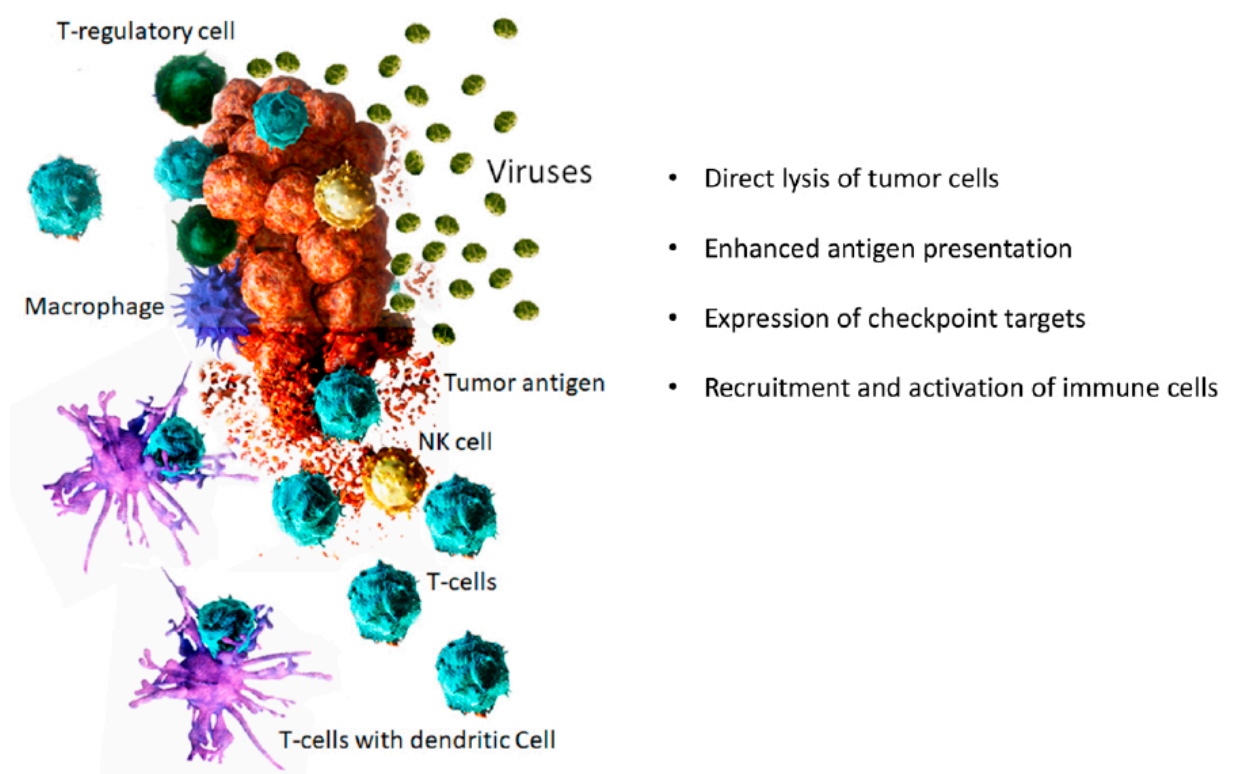

Figure 1. Mechanisms of tumor destruction by oncolytic viruses.

\section{Herpes Simplex Virus-1}

Herpes simplex virus-1 (HSV-1) belongs to the family herpesviridae. It is an enveloped, double-stranded DNA virus with genome size of approximately $150 \mathrm{kbp}$ that encodes $\sim 89$ genes [4]. Many HSV-1-based oncolytic viruses have been evaluated in clinical trials and most of them contain deletions in the neurovirulence gene ICP34.5 [5]. Talimogene laherparepvec, a HSV-1, is the only oncolytic virus to have gained regulatory approvals in the Western world.

\section{1. $T-V E C$}

Talimogene laherparepvec (T-VEC) marketed as Imlygic, is a JS-1 strain of HSV-1 that was originally isolated from a cold sore [6,7]. The virus is attenuated through deletion of both copies of the neurovirulence gene infected cell protein 34.5 (ICP34.5). Furthermore, immunostimulatory properties of T-VEC have been improved by the deletion of the gene ICP47, an inhibitor of major histocompatibility complex I (MHC-I) mediated antigen presentation, and by the insertion of granulocyte-macrophage colony-stimulating factor (GM-CSF) expression cassettes at both loci of ICP34.5. The deletion of ICP47 enhances immune-mediated destruction of the virus-infected cells, whereas virus-encoded GMCSF increases recruitment and activities of dendritic cells, ultimately boosting anti-tumor immunity [7].

In preclinical studies, T-VEC was found to induce strong cytotoxic activities against a wide range of tumor cell lines in vitro and caused tumor regression in murine models [8,9]. Followed by the promising preclinical results, T-VEC was tested for its safety in a Phase I clinical trial that included patients with refractory melanoma, breast cancer, gastric cancer or head and neck cancer [10]. In this trial, patients were primed with intratumoral injection of $10^{6}$ plaque forming units (PFUs) of virus followed by multiple injections of higher doses $\left(10^{7}\right.$ or $10^{8}$ PFUs). The treatment was well tolerated with the most common side effects being local inflammation and erythema febrile responses. Overall responses to the treatment were mild; however, it was encouraging to find that the virus was able to replicate in the tumors, produce GM-CSF, cause tumor necrosis and inflammation in both 
the injected and, in some cases, un-injected tumors. After this Phase I study, an initial Phase II clinical trial was performed that included 50 patients with stage IIIC unresectable or metastatic melanoma [11]. T-VEC was injected intratumorally at $10^{8} \mathrm{PFU}$ at the interval of 2 weeks for up to 24 treatments. Tumor regression was observed not only in the injected lesions, but also in un-injected distant tumors including visceral metastases. The overall response rate (ORR) was $26 \%$ with 8 out of 13 responding patients experiencing a complete response. The treatment was well tolerated with the most common side-effects being inflammation at injection sites, flu-like symptoms and nausea. This encouraging Phase II trial was followed by a Phase III trial, which involved 436 patients with stage IIIB to IV melanoma. In this study, efficacy of intratumoral T-VEC treatment was compared with a subcutaneous injection of GM-CSF [12]. The ORR for T-VEC and GM-CSF was found to be $31.5 \%$, and $6.4 \%$, respectively. Also, $16.9 \%$ of patients treated with T-VEC experienced complete remission [13]. Following this Phase III study, T-VEC was approved by the FDA as monotherapy for unresectable melanoma following initial surgery.

Puzanov et al. reported the findings of a Phase Ib trial of T-VEC in combination with ipilimumab (a cytotoxic T-lymphocyte-associated antigen 4 (CTLA4) checkpoint inhibitor) in patients with advanced melanoma [14]. The combination therapy was found to be safe and the 18-month overall survival was $67 \%$, which was greater than either T-VEC or ipilimumab monotherapy. Likewise, Ribas et al., reported the results of a Phase Ib study combining T-VEC with pembrolizumab (anti-PD-1 antibody) in patients with advanced melanoma [15]. The combination therapy was found to be well tolerated with the most common adverse events being fatigue, fever and chill, and no dose-limiting toxicities occurred. An objective response rate of $62 \%$ was achieved, with a complete response rate of $33 \%$ based on immune-related response criteria. The patients who responded to the combination therapy were those who had increased CD8+ T cells, elevated programmed death ligand 1 (PD-L1) expression and interferon gamma (IFN-y) gene expression after T-VEC treatment. Furthermore, there are more than 20 clinical studies currently recruiting patients (Clinicaltrials.gov; accessed on 1 March 2021) to determine safety and efficacy of T-VEC either as monotherapy or in combination with other therapeutics, including immune checkpoint inhibitors, in different types of cancers. Some of these studies, which are currently in trials, are mentioned in Table 1.

Table 1. Examples of oncolytic herpes simplex viruses (HSVs) currently under clinical trials.

\begin{tabular}{|c|c|c|c|c|c|}
\hline Virus & Transgene & Combination & Tumor Type & Phase & Reference \\
\hline G207 & None & Radiation & Brain tumor & II & NCT04482933 \\
\hline ONCR-177 & $\begin{array}{l}\text { IL-12, CCL4, FLT3LG, } \\
\alpha \text { CTLA4 and } \alpha \text { PD- } 1\end{array}$ & pembrolizumab & $\begin{array}{l}\text { Melanoma and } \\
\text { other solid tumors }\end{array}$ & $\mathrm{I}$ & NCT04348916 \\
\hline $\begin{array}{c}\mathrm{OH} 2 \\
(\mathrm{HSV}-2)\end{array}$ & GM-CSF & $\begin{array}{l}\text { Irinotecan or } \\
\text { HX008 }\end{array}$ & $\begin{array}{l}\text { Gastrointestinal } \\
\text { tumors and other } \\
\text { solid tumors }\end{array}$ & I \& II & NCT03866525 \\
\hline RP1 & GALV-GP and GM-CSF & None & $\begin{array}{l}\text { Cutaneous } \\
\text { squamous cell } \\
\text { carcinoma }\end{array}$ & IB & NCT04349436 \\
\hline RP1 & GALV-GP and GM-CSF & Cemiplimab & $\begin{array}{l}\text { Cutaneous } \\
\text { squamous cell } \\
\text { carcinoma }\end{array}$ & $\mathrm{I}$ & NCT04050436 \\
\hline $\mathrm{RP} 2$ & GALV-GP and GM-CSF & Nivolumab & $\begin{array}{l}\text { Advanced solid } \\
\text { tumors }\end{array}$ & $\mathrm{i}$ & NCT03767348 \\
\hline T-VEC & GM-CSF & $\begin{array}{l}\text { Ipilimumab and } \\
\text { Nivolumab }\end{array}$ & Breast Cancer & I & NCT04185311 \\
\hline T-VEC & GM-CSF & None & $\begin{array}{c}\text { Angiosarcoma of } \\
\text { skin }\end{array}$ & II & NCT03921073 \\
\hline T-VEC & GM-CSF & Pembrolizumab & Sarcoma & II & NCT03069378 \\
\hline T-VEC & GM-CSF & Pembrolizumab & $\begin{array}{l}\text { Cutaneous } \\
\text { melanoma }\end{array}$ & II & NCT03842943 \\
\hline
\end{tabular}




\section{2. $G 207$}

G207 is another oncolytic HSV-1 that has completed several Phase I trials and is expected to begin a Phase II trial soon. Similar to T-VEC, G207 has deletions in both copies of ICP34.5 genes. Additionally, G207 has the ICP6 gene inactivated through the insertion of the Escherichia coli lacZ gene. The ICP6 gene encodes a viral homolog of the cellular protein ribonucleotide reductase (RR), an enzyme required for the production of deoxy-ribonucleotides (dNTPs) [16]. Deletion of ICP6 restricts virus replication to dividing cells with high levels of RR such as cancer cells. While this virus was originally designed for treatment of brain tumors, preclinical studies have found that the virus is effective against a wide range of cancer types including prostate, breast, head and neck, colon, ovaries, neuroblastoma, osteosarcoma and melanoma [17-22]. Results from the first clinical study of G207 were reported by Markert et al. [23]. A total of 21 patients with glioblastoma multiforme were enrolled in this study. The patients received $10^{6}$ to $3 \times 10^{9}$ PFUs of the virus intratumorally. Some patients experienced adverse events, but toxicities were not directly related to the virus. Radiographic and neuropathologic analysis showed some evidence of anti-tumor activity. In another Phase I study, nine patients with recurrent malignant glioma were treated intratumorally with $10^{9}$ PFUs of G207 followed by treatment with 5 Gy radiation [24]. This combination treatment was well tolerated. In terms of efficacy, six of the nine patients had stable or partial response for at least one time point. A Phase II trial combining G207 with radiation therapy is expected to begin soon in pediatric patients with gliomas.

\section{3. $G 47 \Delta$}

G47 $\Delta$ is a variant of G207 that has also been tested for safety and efficacy in glioblastoma and prostate cancer in Japan. G47 $\triangle$ has an additional deletion in the gene ICP47, which allows for enhanced MHC-I presentation on infected cells [22]. Interim analysis from a Phase II study in glioblastoma patient showed that the 1-year survival rate for G47 $\Delta$ treated patients ( $n=13$ patients) was significantly higher $(92.3 \%)$ than the control group (15\%) [25]. Severe adverse events (grade 2 fever) were observed in 2 out of 13 patients. Results of the Phase II study were published in late 2019 and this oncolytic virus has been designated as a "breakthrough therapy" drug by the Japanese government; thus, a fast track approval is expected [25].

\subsection{ONCR-177}

ONCR-177 is an oncolytic HSV-1 virus developed by Oncorus Inc. Unlike T-VEC and G207, ONCR-177 is not deleted in ICP34.5 genes [26]. Target sequences for tissue-specific microRNAs (miRNA) are inserted into early genes (ICP4, ICP27, UL8), and in ICP34.5, that potently inhibit virus replication in normal cells, but not in cancer cells [26]. Furthermore, the virus contains mutations in the UL37 gene that prevent axonal retrograde transport as well as latency, ensuring that virus will not damage neurons. Additionally, ONCR-177 encodes five immune-modulatory transgenes (IL-12, CCL4, FLT3LG, anti-CTLA4 and antiPD-L1) driven by a dual bi-directional promoter [27]. ONCR-177 is currently in Phase I trial to determine the maximum tolerated dose and preliminary efficacy as monotherapy and in combination with pembrolizumab (NCT04348916).

\section{5. $R P 1 / 2$}

RP1 is an oncolytic HSV-1 virus containing deletions in the neurovirulence genes ICP34.5 and ICP47. It has two transgenes inserted in its genome: GM-CSF and gibbon ape leukemia virus glycoprotein (GALV-GP R-), a fusogenic membrane glycoprotein. This virus is currently in Phase I trial as monotherapy for recurrent or advanced cutaneous squamous cell carcinoma (NCT04349436) or in combination with anti-PD-1 antibody (NCT04050436). RP1 has been further modified (known as RP2) to express anti-CTL4, which is also undergoing a Phase I trial (NCT03767348). 


\section{Vaccinia Virus}

Vaccinia virus (VACV) is an enveloped virus belonging to the family poxviridae. VACV has a linear double-stranded DNA genome that is approximately $200 \mathrm{kpb}$ in size and encodes $\sim 200$ genes [28]. VACV is one of the most intensively studied viruses for use in oncolytic therapy. VACV was used as a vaccine for the successful eradication of smallpox throughout the world, and thus, has a long-established safety profile in humans. Among many different oncolytic VACVs, Pexa-Vec is the most advanced one that has completed many clinical studies.

\subsection{Pexa-Vec}

Pexa-Vec (formerly JX-594) is a Wyeth strain of vaccinia virus that has $J 2 R$, encoding for thymidine kinase, replaced by the expression cassettes for human GM-CSF (hGM-CSF) and lacZ [29]. Pexa-Vec was deleted in J2R with the aim of increasing its cancer-specificity, and the hGM-CSF expression cassette was inserted with the aim of increasing anti-tumor immunity through the recruitment and activation of antigen-presenting cells (APCs) and cytotoxic T lymphocytes (CTLs) [29]. The construction of JX-594 and evaluation of its oncolytic properties was first reported by Kim et al. in 2006 [29]. In this study, the authors used two immune-competent orthotopic liver tumor models: a rabbit model with timedependent metastases to lungs, and a carcinogen-induced rat liver tumor model [29]. While both rabbit and rat tumors support the replication of vaccinia virus, human GM-CSF is only partially active in rabbits and is inactive in rats. After the establishment of orthotopic tumors, rabbits were treated with $10^{9}$ PFUs of JX-594 intratumorally or intravenously. Compared to the control group, the intratumoral or intravenous injection of JX-594 potently inhibited the growth of primary tumors. Furthermore, while all control-treated rabbits developed lung metastases, none of the rabbits treated with JX-594 developed lung metastases. Interestingly, in the rat model in which human GM-CSF is not compatible, $10^{8}$ PFUs of JX-594 injected three times (intravenous) at the interval of 2 weeks, resulted in a complete tumor regression in majority of the treated mice. This study by Kim et al. was encouraging, especially because it involved immune-competent orthotopic tumor models, as opposed to other studies, most of which used human xenograft models and intratumoral injections for the evaluation of oncolytic viruses.

The prototype of JX-594 was used in a pilot Phase I trial in 1998 [30]. The virus used was a New York City Board of Health strain of VACV in which the J2R gene was replaced with expression cassettes for hGM-CSF and $\beta$-galactosidase. In this study, a total of seven patients with unresectable melanoma were treated twice weekly with intratumoral injections of escalating doses of the virus for 6 weeks. A maximum dose of $8 \times 10^{7} \mathrm{PFU}$ virus was used in the study and no maximum tolerable dose (MTD) was reached. Tumor regression in a fraction of patients was observed in this study, and systemic toxicity was limited to flu-like symptoms that resolved within $24 \mathrm{~h}$. Followed by this pilot study, an open-label Phase I dose-escalation trial was conducted with substantially higher doses with the aim of defining safety and the MTD of JX-594 [31]. This study recruited 14 patients with refractory primary or metastatic hepatocellular carcinoma. Patients received intratumoral injection of the virus ranging in doses from $10^{8} \mathrm{PFU}$ to $3 \times 10^{9} \mathrm{PFU}$ every 3 weeks. Grade 1-3 flu-like symptoms were observed in all patients and 4 out of 14 patients experienced transient grade 1-3 dose-related thrombocytopenia. Furthermore, patients treated with the highest dose $\left(3 \times 10^{9} \mathrm{PFU}\right)$ displayed hyperbilirubinemia, which was considered doselimiting. From this study, $1 \times 10^{9}$ PFU was determined to be the MTD for JX-594. In addition to finding the MTD, several insights were gained from this Phase I trial. First, the study showed that it is possible for the virus to disseminate from injected to non-injected tumors through blood; virus replication and expression of GM-CSF were also confirmed. Second, tumor responses were observed in both injected and non-injected tumors. In terms of efficacy, out of 10 radiographically evaluable patients, 3 had partial response, 6 had stable disease and 1 had progressive disease. 
Liu et al. reported another pilot study of JX-594 in advanced refractory hepatitis $B$ virus (HBV)-associated hepatocellular carcinoma (HCC) [32]. The virus was injected intratumorally in a total of three patients, with the highest dose being $3 \times 10^{9} \mathrm{PFU}$. In this study, virus treatment was found to be safe and anti-tumor efficacy was observed in all patients despite the presence of high levels of neutralizing antibodies. JX-594 was found to replicate in tumors and release of virus in circulation was observed. Additionally, this study showed that the virus treatment elevated the levels of anti-vascular cytokines, resulting in tumor vascular shutdown. Interestingly, JX-594 was also found to suppress the replication of hepatitis B virus in HCC patients. Another pilot study was reported by Heo et al. in 2011 on the combination of JX-594 with the kinase inhibitor, sorafenib, for the treatment of HCC [33]. In murine models, treatment of tumors with JX-549 followed by treatment with sorafenib resulted into superior anti-tumor efficacy than either agent alone. In human patients, the sequential treatment was well tolerated and associated with objective tumor responses.

In 2011, Breitbach et al. reported the findings from a Phase I dose-escalation trial of a single intravenous infusion of JX-594 [34]. The maximum dose used in the study was approximately $2 \times 10^{9} \mathrm{PFU}$, which was generally well tolerated. This study included a total of 23 patients. The virus was detectable in tumor biopsies of patients who received virus at the dose $\geq 10^{9} \mathrm{PFU}$. This study provided the proof-of-concept regarding the feasibility of the systemic administration of JX-594 for the treatment of tumors.

Results from a Phase II dose-finding trial for JX-594 in liver cancer treatment were reported by Heo et al. in 2013 [35]. A total of 30 patients were enrolled in this study. Two doses of virus $10^{8} \mathrm{PFU}$ (low-dose) and $10^{9} \mathrm{PFU}$ (high-dose) were used for intratumoral infusions on day 1, 15 and 29 in patients with advanced hepatocellular carcinoma. The objective of this study was to compare the safety and efficacy of low- and high-dose treatments and induction of immunity against both cancer cells and the oncolytic virus. The objective response rate (15\%) and intrahepatic disease control $(50 \%)$ were found to be equivalent in the injected and non-injected distant tumors for both the doses. GM-CSF expression and the induction of anti-tumor immunity was observed at both the doses. While the tumor response rate and immune endpoints were similar for the low- and highdose treatments, survival of patients treated with the high-dose treatment was significantly higher (median survival 14.1 months) than that for patients treated with the low-dose treatment (6.7 months).

Recently, results from a multicenter Phase IIb trial of Pexa-Vec in sorafenib-resistant hepatocellular carcinoma (TRAVERSE) were published by Moehler et al. [36]. Patients received best supportive care (BSC) alone or BSC plus Pexa-Vec. A single intravenous infusion $\left(10^{9} \mathrm{PFU}\right)$ was followed by up to five intratumoral injections. The treatment was generally well tolerated and evidence of immune induction against the virus as well as tumor antigens were observed. However, in this study Pexa-Vec failed to improve the survival of patients; the overall survival of patients treated with BSC alone (4.2 months) was not significantly different from the overall survival of patients treated with BSC plus Pexa-Vec. Currently, Pexa-Vec is being tested in combination with sorafenib in a worldwide Phase III PHOCUS trial in HCC patients.

Thus far, more than a dozen clinical trials have been completed with JX-594 (Pexa-Vec) in multiple types of malignancies, in which more that 400 patients have been injected with the virus. The MTD has been determined to be $10^{9}$ PFU. While all these studies have established an excellent safety profile for this virus, the anti-tumor efficacy of the virus remains uncertain.

\subsection{GL-ONC1}

GL-ONC1 (formerly known as GLV-1h68) is an oncolytic VACV based on the Lister strain developed by Genelux Corporation [37]. Like JX-594, GL-ONC1 is deleted in the J2R gene. Additionally, GL-ONC1 is deleted in the F14.5L and A56R genes. The virus encodes three transgenes: $\beta$-galactosidase, $\beta$-glucuronidase and Renilla luciferase-Aequorea green 
fluorescent protein [37]. In preclinical studies, the virus was found to be safe and efficacious against a variety of malignancies including colon cancer, breast cancer, glioma, ovarian cancer, pancreatic cancer and prostate cancer [38-42]. Followed by encouraging preclinical results, the virus has been evaluated in multiple early-stage clinical trials, where the virus was administered either intratumorally or intravenously. GL-ONC1 has been well tolerated in patients and no MTD was reached in any of the studies. While there has been some evidence of anti-tumor efficacies in early phase trials, further trials are needed to determine the overall anti-tumor efficacy of this virus.

\section{3. $v v D D$}

The vvDD (also called JX-929 or vvDD-CDSR) is a Western Reserve (WR) strain of VACV that is deleted in $J 2 R$ and $C 11 R$ (vaccinia growth factor) genes, and it encodes bacterial cytosine deaminase as well as the somatostatin receptor [43]. The WR strain of VACV is considered a laboratory strain that was never used as a vaccine. Although the WR strain is known to exert superior oncolytic activity compared to other strains of VACV, the WR strain has only been used in two clinical studies thus far [44]. Deletion of $J 2 R$ and C11R allows for vvDD to selectively replicate in cells with an active E2F and epidermal growth factor receptor (EGFR/Ras) pathway, common features of many cancer cells [43-45]. The vvDD virus was found to exert potent anti-tumor efficacy against colon cancer, ovarian cancer and liver metastases in preclinical studies [43-45]. Followed by the encouraging preclinical results, a first-in-man study of vvDD was performed to determine the safety, systemic spread and anti-tumor efficacy in patients with solid tumors, and the findings of this study were reported in early 2015 by Zeh et al. [43]. In this dose-escalation study, up to $3 \times 10^{9}$ PFU of virus, the maximum feasible dose, was injected intratumorally without dose-limiting toxicities. The virus was recovered from both injected and non-injected tumors. Although no clinical benefits were achieved in this study, it was encouraging to see that the WR strain of VACV was well tolerated even at the maximum feasible dose of $3 \times 10^{9}$ PFU.

The second clinical study using vvDD was published by Downs-Canner et al. in 2016 [46]. In this Phase I study, vvDD was delivered intravenously in 11 patients with advanced colorectal or other solid tumors. A maximum of $3 \times 10^{9} \mathrm{PFU}$ virus was injected in patients. The virus was well tolerated with the most common adverse events being grade $1 / 2$ flu-like symptoms. Tumor-specific replication of the virus was observed. Clinical benefits were minimal, but the authors concluded that excellent safety profile of the virus warrants further trials in combination with other therapeutics such as checkpoint inhibitors. Table 2 shows examples of VACVs in clinical trials.

Table 2. Examples of oncolytic vaccinia viruses (VACVs) in clinical trials.

\begin{tabular}{|c|c|c|c|c|c|c|}
\hline Virus & Transgene & Combination & Tumor Type & Phase & Status & Reference \\
\hline Pexa-Vec & GM-CSF & $\begin{array}{l}\text { REGN2810 } \\
\text { (anti-PD-1) }\end{array}$ & $\begin{array}{l}\text { Renal cell } \\
\text { carcinoma }\end{array}$ & $\mathrm{I}$ & Recruiting & NCT03294083 \\
\hline Pexa-Vec & GM-CSF & Ipilimumab & $\begin{array}{l}\text { Any except liver } \\
\text { cancer }\end{array}$ & $\mathrm{I}$ & Recruiting & NCT02977156 \\
\hline Pexa-Vec & GM-CSF & $\begin{array}{l}\text { Cyclophosphamide } \\
\text { and Avelumab }\end{array}$ & $\begin{array}{l}\text { Solid tumors and } \\
\text { soft tissue } \\
\text { sarcoma }\end{array}$ & I \& II & Recruiting & NCT02630368 \\
\hline Pexa-Vec & GM-CSF & Sorafenib & $\begin{array}{l}\text { Hepatocellular } \\
\text { carcinoma }\end{array}$ & II & Completed & NCT01171651 \\
\hline Pexa-Vec & GM-CSF & None & $\begin{array}{l}\text { Hepatocellular } \\
\text { carcinoma }\end{array}$ & II & Completed & NCT01636284 \\
\hline Pexa-Vec & GM-CSF & $\mathrm{BSC}$ & $\begin{array}{l}\text { Hepatocellular } \\
\text { carcinoma }\end{array}$ & II & Completed & NCT01387555 \\
\hline T601 & FCU1 & 5-Fluorocytosine & Solid tumors & I \& II & Recruiting & NCT04226066 \\
\hline TBio-6517 & $\begin{array}{l}\text { FLT3L, IL-12, } \\
\alpha \text { CTLA-4 }\end{array}$ & Pembrolizumab & Solid Tumors & I \& II & Recruiting & NCT04301011 \\
\hline
\end{tabular}


Table 2. Cont.

\begin{tabular}{|c|c|c|c|c|c|c|}
\hline Virus & Transgene & Combination & Tumor Type & Phase & Status & Reference \\
\hline GL-ONC1 & $\begin{array}{c}\text { Luc-GFP, } \\
\beta \text {-Galactosidase } \\
\beta \text {-glucuronidase }\end{array}$ & Bevacizumab & $\begin{array}{l}\text { Ovarian cancer, } \\
\text { peritoneal } \\
\text { carcinomatosis } \\
\text { and cancer of } \\
\text { fallopian tube }\end{array}$ & I \& II & Recruiting & NCT02759588 \\
\hline GL-ONC1 & $\begin{array}{c}\text { Luc-GFP, } \\
\beta \text {-Galactosidase } \\
\beta \text {-glucuronidase }\end{array}$ & None & $\begin{array}{l}\text { Head and neck } \\
\text { cancer }\end{array}$ & I & Completed & NCT01584284 \\
\hline GL-ONC1 & $\begin{array}{c}\text { Luc-GFP, } \\
\beta \text {-Galactosidase } \\
\beta \text {-glucuronidase }\end{array}$ & None & Solid tumors & I & Completed & NCT00794131 \\
\hline vvDD & $\begin{array}{c}\text { Cytosine } \\
\text { deaminase and } \\
\text { somatostatin } \\
\text { receptor }\end{array}$ & None & Solid tumors & $\mathrm{I}$ & Completed & NCT00574977 \\
\hline
\end{tabular}

\section{Adenovirus}

Adenoviruses are non-enveloped viruses with linear double-stranded DNA genome that ranges from 26 to $45 \mathrm{kbp}$ in size [47]. A search on Clinicaltrials.gov for the term "oncolytic adenovirus" displayed a total of 45 studies in different phases of trials, out of which 11 have been completed and 14 are currently recruiting patients. An oncolytic adenovirus called H101 (also called Oncorine), is the first oncolytic virus to be approved for the treatment of cancer. H101 is an E1B-deleted adenovirus type 5 that was approved in China in November 2005 for the treatment of head and neck cancer [48]. Despite many trials in North America and Europe, oncolytic adenovirus has not been approved in these countries because the virus has failed to demonstrate meaningful anti-tumor efficacy. However, several investigators have developed modified strains of adenoviruses, which have shown greatly enhanced oncolytic potentials in preclinical studies. This has renewed the interest in pursuing adenovirus as an oncolytic agent.

\subsection{DNX-2401}

DNX-2401 (also known as Delta-24-RGD) is an oncolytic adenovirus in which the early gene E1A is inactivated through the deletion of $24 \mathrm{bp}$ in the E1A gene [49]. E1A inactivation allows this virus to selectively replicate in cells with non-functional retinoblastoma protein, which is found in the majority of cancers [50]. Also, the fiber knob protein in this virus has been modified through the insertion of an arg-gly-asp (RGD) motif to target integrins on cancer cells as its primary receptor [49]. This virus has been studied mainly for the treatment of brain cancer. According to clinicaltrials.gov (accessed on 1 March 2021), DNX2401 has completed four Phase I trials in patients with brain tumors/glioblastoma and one Phase I trial in patients with ovarian cancer and primary peritoneal cancer. In brain cancer patients, the virus has been studied as a single agent or in combination with other therapeutics such as interferon-y, temozolomide or pembrolizumab. While results from most of the studies have not been published, in 2019 Philbrick and Adamson published the findings of a Phase I study of DX-2401 in patients with recurrent high-grade gliomas [51]. In this study, 14 days after intratumoral injection of the virus, injected tumor was surgically removed from one group of patients but not from another group. The median overall survival (mOS) was 13.5 months in patients that underwent surgical resection, whereas the mOS was 9.5 months in patients that did not undergo surgical resection. The virus was well tolerated with no grade 3/4 adverse events. Currently there are two active trials listed for this virus: a Phase I trial in combination with conventional surgery and a Phase II trial in combination with pembrolizumab. 


\subsection{Enadenotucirev}

Kuhn et al. used recombination and a directed evolution approach to create a chimeric group B oncolytic adenovirus called Enadenotucirev [52]. This virus is a chimera of adenovirus type 11 and adenovirus type 3, which was derived from a pool of seven different adenovirus serotypes used to infect human colorectal cancer cells HT-29. In preclinical studies the virus was found to demonstrate a 2-log increase in potency and selectivity in vitro when compared to one of the most studied oncolytic adenovirus ONYX015. Furthermore, the virus was found to be much more potent than parental viruses and Onyx-015 in murine models and in human tumors ex vivo [52]. To date, three Phase I studies have been completed with this virus. Results from one of the Phase I studies were published by Machiels et al. in 2019. In this study, 61 patients with advanced epithelial tumors were enrolled and a maximum of $10^{13}$ virus particles were administered through intravenous infusion. The most common adverse events of grade 3 were hypoxia, lymphopenia and neutropenia, which were manageable [53]. There are currently two active Phase I studies with Enadenotucirev that are recruiting patients. The first one is recruiting patients with metastatic or advanced colorectal cancer, head and neck cancer or other epithelial tumors (NCT02636036). In this study, Enadenotucirev will be used in combination with nivolumab (PD-1 inhibitor). Another Phase I trial with Enadenotucirev is recruiting patients with locally advanced rectal cancer (NCT03916510), and patients will be treated with the virus in combination with radiotherapy and chemotherapy (capecitabine).

\section{3. $\mathrm{LOAd703}$}

LOAd703 is another oncolytic adenovirus that has shown promising results in preclinical studies and is actively being tested in clinical studies for the treatment of a variety of cancers [54]. LOAd703 encodes two immune-stimulatory proteins: a trimerized CD40 ligand and a 4-1BB ligand. There are currently three active clinical trials involving LOAd703 that are recruiting patients for Phase I or II studies (Table 3). The first one is recruiting patients with pancreatic adenocarcinoma, ovarian cancer, biliary carcinoma and colorectal cancer (NCT03225989). In this Phase I study, patients will be treated with LOAd703 as monotherapy. The second one is recruiting patients with malignant melanoma, who will be treated with LOAd703 in combination with the checkpoint inhibitor atezolizumab in Phase I and II studies (NCT04123470). The third clinical study involving LOAd703 is currently recruiting pancreatic cancer patients, who will be treated with the virus in combination with gemcitabine, nab-paclitaxel and atezolizumab (NCT02705196).

Table 3. Examples of clinical trials with adenoviruses.

\begin{tabular}{|c|c|c|c|c|c|c|}
\hline Virus & Transgene & Combination & Tumor Type & Phase & Status & Reference \\
\hline LOAd703 & $\begin{array}{l}\text { CD40L, } \\
4-1 B B L\end{array}$ & None & $\begin{array}{l}\text { Pancreatic cancer, } \\
\text { ovarian cancer, } \\
\text { biliary carcinoma, } \\
\text { colorectal cancer }\end{array}$ & $1 \& 2$ & Recruiting & NCT03225989 \\
\hline LOAd703 & $\begin{array}{l}\text { CD40L, } \\
\text { 4-1BBL }\end{array}$ & atezolizumab & $\begin{array}{l}\text { Malignant } \\
\text { Melanoma }\end{array}$ & $1 \& 2$ & Recruiting & NCT04123470 \\
\hline LOAd703 & $\begin{array}{l}\text { CD40L, } \\
4-1 B B L\end{array}$ & $\begin{array}{c}\text { Gemcitabine, } \\
\text { nab-paclitaxel and } \\
\text { atezolizumab }\end{array}$ & Pancreatic cancer & $1 \& 2$ & Recruiting & NCT02705196 \\
\hline TILT-123 & $\begin{array}{l}\text { hIL-2, } \\
\text { TNFa }\end{array}$ & None & $\begin{array}{l}\text { Metaststic } \\
\text { melanoma }\end{array}$ & 1 & Recruiting & NCT04217473 \\
\hline DNX-2440 & OX40L & None & Glioblastoma & 1 & Recruiting & NCT03714334 \\
\hline CG0070 & GM-CSF & None & Bladder cancer & 2 & Completed & NCT02365818 \\
\hline Delta-24-RGD & None & None & Brain tumor & $1 \& 2$ & Completed & NCT01582516 \\
\hline MG1-MAGEA3 & MAGEA3 & $\begin{array}{l}\text { Pembrolizumab, } \\
\text { Ad-MAGEA3 }\end{array}$ & NSCLC & $1 \& 2$ & Completed & NCT02879760 \\
\hline
\end{tabular}




\subsection{ONCOS-102}

Another oncolytic adenovirus being tested in clinical studies is ONCOS-102 (previously called CGTG-102). ONCOS-102 is a chimeric adenovirus constructed from adenovirus type 3 and 5, and is armed with the cytokine GM-CSF [55]. Thus far, the virus has completed one Phase I study and several more studies are currently recruiting patients for testing the safety and efficacy of this virus as a monotherapy or in combination with other therapies. In the first clinical study, 12 patients with advanced-stage solid tumors, refractory to available treatments, were recruited for a dose-escalation study [56]. Patients were treated intratumorally with multiple injections of virus doses ranging from $3 \times 10^{10}$ to $3 \times 10^{11}$ virus particles in combination with low-dose cyclophosphamide. No doselimiting toxicity was observed, and hence, no MTD was identified in this study. In terms of anti-tumor efficacy, 4 out of 10 evaluable patients had stable disease at 3 months. Patients treated with the virus had a short-term elevation in pro-inflammatory cytokines and had an increase in tumor infiltration by lymphocytes, as determined by the immunohistochemistry of tumor biopsies before and after the treatment. In some patients, systemic induction of tumor-specific CD8+ T cells was observed. Furthermore, an upregulation in the levels of PD-L1 in the tumor was observed after virus treatment, suggesting that the efficacy of the virus could be enhanced by combining it with PD-L1 inhibitors. Hence, there are active clinical studies testing the safety and efficacy of ONCOS-102 in combination with PD-L1 inhibitors such as durvalumab (NCT02963831) and pembrolizumab (NCT03003676).

\subsection{RNA Viruses}

RNA viruses belonging to different families including coronaviridae, picornaviridae, reoviridae, retroviridae, rahabdoviridae and togaviridae have been studied for their oncolytic activities [57]. One common feature of RNA viruses is that they generate doublestranded RNA during their life-cycle, which causes the activation of cellular defense mechanisms, including the activation of protein kinase R (PKR) and the release of interferon [58]. However, majority of cancers have defective PKR signaling and interferon response pathways, making them naturally susceptible to RNA viruses. While many oncolytic RNA viruses have completed Phase I trials, the most advanced oncolytic RNA virus that has completed Phase I, II and III studies is reolysin (a reovirus). In this article we focus on reolysin as an example of oncolytic RNA virus.

\section{Reovirus}

Reoviruses are non-enveloped viruses with double-stranded, segmented RNA genome. The total genome size is $23.5 \mathrm{kbp}$, which is divided into 10 segments [59,60]. Wild-type reovirus preferentially replicates in cancer cells, ultimately leading to lysis of those cells [61]. Cancer selectivity of reovirus has been shown to be due to the overexpression of the oncogene Ras and the impairment in type-I interferon (IFN) signaling [62]. Reovirus is one of the most commonly studied viruses for its oncolytic usage. Reolysin (also known as Pelareorep), an unmodified reovirus type 3, Dearing strain [63], is the most advanced oncolytic reovirus that has completed multiple clinical trials. According to Clinicaltrials.gov (accessed in 1 November 2020), a total of 20 clinical trials have been completed with this virus (6 Phase I trials, 13 Phase II trials and 1 Phase III trial). The virus has been studied as a monotherapy or in combination with other therapeutics for the treatment of a multitude of cancers including metastatic breast cancer, advanced-stage head and neck cancer, metastatic ovarian cancer, malignant gliomas, prostate cancer and metastatic melanoma. Out of the total 20 completed trials, Reolysin was used as monotherapy in 5 studies, and in the remaining 15 studies it was combined with chemotherapeutics such as gemcitabine, irinotecan, docetaxel, carboplatin, paclitaxel and cyclophosphamide (Table 3). Currently, there are five clinical trials on Reolysin which are active and recruiting patients. 


\subsection{Reolysin as Monotherapy}

Results of a Phase I trial of Reolysin were published in 2013 by Morris et al. [64]. In this study, a total of 19 patients with advanced-stage solid tumors including breast cancer, head and neck cancer and melanoma were enrolled. Up to $1 \times 10^{10} \mathrm{PFU}$ virus was injected intratumorally and patients were monitored for safety and efficacy. Treatment was well tolerated with the most common toxicities being grade 2 local erythema and transient flu-like symptoms. All patients showed increasing levels of antibody titers against the virus. In terms of efficacy, 7 out of 19 patients demonstrated some level of anti-tumor response in the injected tumors: 1 had complete response, 2 had partial response and 4 had stable disease.

Vidal et al. reported the first clinical study on intravenous delivery of Reolysin [65]. In this Phase I study, a total of 33 patients with advanced cancer were treated intravenously with escalating doses of the virus, up to $3 \times 10^{10}$ tissue culture infective dose (TCID50) for five consecutive days every 4 weeks. Grade 1 and 2 toxicities included fever, fatigue and headaches, which were independent of the virus doses. Virus-neutralizing antibodies were developed in all patients, with the peak titer detected 4 weeks after the first injection. Evidence of virus localization and replication in tumor was observed in three patients. The study report did not mention anything about anti-tumor efficacy, perhaps because no anti-tumor efficacy was observed.

Gollamudi et al. reported results from another clinical study involving intravenous administration of Reolysin [66]. In this dose-escalation study, 18 patients with advancedstage solid tumors were treated with Reolysin intravenously every 4 weeks in doses ranging from $1 \times 10^{8}$ to $3 \times 10^{9} \mathrm{TCID} 50$. Dose-limiting toxicity was not reached, and the common treatment-related toxicities included fatigue and fever. A virus-neutralizing antibody was developed in all patients during the course of treatment. Furthermore, virus shedding was observed in 6 out of 18 patients, and the patients showing virus shedding appeared to be more responsive to the treatment. In this study, the overall clinical benefit rate was $45 \%$ : one patient experienced partial response and seven attained stable disease.

The first Phase II trial for intravenous monotherapy of Reolysin was initiated in 2008 [67]. In this study, 21 patients with metastatic melanoma were treated intravenously with $3 \times 10^{10}$ TCID50 on days $1-5$ of each 4 week cycle. Similar to previous Phase I trials, the treatment was well tolerated. Productive reovirus replication was observed in the tumor biopsies of two patients. Unfortunately, no objective response was observed in this study. Likewise, results from another Phase II trial were reported by Mite et al. (NCT00503295). In this study, 43 patients with bone and soft tissue sarcoma metastatic to the lung were recruited. Patients were treated intravenously with Reolysin every 28 days. Toxicities were mild to moderate, including fever, chills, fatigue, diarrhea, cough, dyspnea, neutropenia and thrombocytopenia. Overall, 14 patients experienced stable disease for more than 2 months, and 5 patients had stable disease for more than 6 months.

\subsection{Reolysin in Combination with Other Therapies}

While clinical studies with Reolysin as monotherapy have demonstrated that the virus is safe, the lackluster efficacy of the virus as monotherapy has prompted investigators to combine it with other therapeutics. Over a dozen clinical studies encompassing different phases of trials have been completed so far with Reolysin in combination with radiation, chemo- or biological therapies. Harrigton et al. reported the findings of a Phase I trial combining reovirus in patients receiving palliative radiotherapy [68]. In total, 23 patients with various solid tumors of advanced stages were treated in two stages. In the first stage, patients received $20 \mathrm{~Gy}$ of radiation followed by two intratumoral injections of reovirus at doses between $1 \times 10^{8}$ and $1 \times 10^{10}$ TCID50. In the second stage, patients received a higher dose of radiation ( $36 \mathrm{~Gy}$ ) followed by 2,4 or 6 doses of $1 \times 10^{10}$ TCID50 virus. The combination treatments were found to be safe with mild (grade 1 to 2 ) toxicities. Two of seven evaluable patients in the low-dose radiation group showed partial response, and five patients had stable disease. Likewise, in the high-dose radiation treatment, five of 
seven evaluable patients experienced partial response and two had stable disease. No virus shedding was detected in blood, urine, stool and sputum of the patients. Given the excellent safety profile and better efficacy, compared to previous studies using reovirus as monotherapy, the authors concluded that this combination should be evaluated in newly diagnosed patients receiving radiation with curative intent.

Lolkema et al. reported results of the first clinical study combining reovirus with a chemotherapy [69]. In this Phase I study, 16 patients with advanced-stage cancers receiving gemcitabine were treated with a single dose of up to $3 \times 10^{10}$ TCID50 reovirus. Overall, 3 out of 16 patients experienced dose-limiting toxicity, with 2 patients having liver enzymes increased to grade 3 , and 1 patient with levels of troponin elevated to grade 3 . The increase in liver enzymes was found to be transient and reversible. In this combination treatment, neutralizing-antibody responses to reovirus were delayed and attenuated. Following this study, a Phase II study was initiated to evaluate the safety and efficacy of reovirus in combination with gemcitabine in patients with metastatic pancreatic cancer (NTC00998322). As of today, this study has been completed but findings of the study have not been published. A variety of other chemotherapeutics including carboplatin, irinotecan, cyclophosphamide, paclitaxel and docetaxel have been studied in combination with Reolysin in Phase I and/or Phase II trials against a multitude of cancers. Finally, a Phase III trial of Reolysin in combination with carboplatin and paclitaxel has been completed in patients with head and neck cancer. Findings of the study have not been reported yet.

Reolysin has also been studied in combination with other biological therapeutics. The first biological therapeutic to be combined with Reolysin was bevacizumab, a monoclonal antibody against vascular endothelial growth factor. In a Phase I trial, colorectal cancer patients with mutant KRAS were treated with Reolysin and bevacizumab together with the chemotherapeutics irinotecan, leucovorin and 5-fluorouracil (NCT01274624). The study has been completed, but the results have not been published yet. Additionally, several clinical studies combining reovirus with checkpoint inhibitors (CKIs) are currently underway (Table 4).

Table 4. Examples of clinical trials with Reolysin.

\begin{tabular}{|c|c|c|c|c|}
\hline Combination & Tumor Type & Phase & Status & Reference \\
\hline Paclitaxel & $\begin{array}{l}\text { Ovarian cancer, peritoneal } \\
\text { carcinomatosis and cancer of } \\
\text { fallopian tube }\end{array}$ & 2 & Completed & NCT01199263 \\
\hline None & Sarcoma & 2 & Completed & NCT00503295 \\
\hline $\begin{array}{l}\text { Carboplatin } \\
\text { Paclitaxel }\end{array}$ & NSCLC & 2 & Completed & NCT00861627 \\
\hline $\begin{array}{c}\text { Irinotecan, } \\
\text { Leucovorin, } \\
\text { 5-FU, Bevacizumab }\end{array}$ & Colorectal cancer & 1 & Completed & NCT01274624 \\
\hline $\begin{array}{l}\text { Carboplatin } \\
\text { Paclitaxel }\end{array}$ & Head and Neck cancer & 3 & Completed & NCT01166542 \\
\hline None & Malignant glioma & 1 & Completed & NCT00528684 \\
\hline $\begin{array}{l}\text { Carboplatin } \\
\text { Paclitaxel }\end{array}$ & Lung Cancer & 2 & Completed & NCT00998192 \\
\hline $\begin{array}{l}\text { Carboplatin } \\
\text { Paclitaxel }\end{array}$ & Head and neck cancer & 2 & Completed & NCT00753038 \\
\hline $\begin{array}{l}\text { Carboplatin } \\
\text { Paclitaxel }\end{array}$ & Metastatic melanoma & 2 & Completed & NCT00984464 \\
\hline $\begin{array}{l}\text { Paclitaxel, } \\
\text { Avelumab }\end{array}$ & Metastatic breast cancer & 2 & Recruiting & NCT04215146 \\
\hline $\begin{array}{c}\text { Carfilzomib, } \\
\text { Dexamethasone, Nivolumab }\end{array}$ & $\begin{array}{l}\text { Recurrent Plasma cell } \\
\text { myeloma }\end{array}$ & 1 & Recruiting & NCT03605719 \\
\hline Retifanlimab & TNBC & 2 & Recruiting & NCT04445844 \\
\hline
\end{tabular}




\section{Conclusions and Perspectives}

The field of oncolytic virotherapy is rapidly growing, with thousands of preclinical studies reported, and over 100 clinical trials performed thus far. The approval of T-VEC by the FDA in 2015 amplified the interest of cancer researchers and clinicians in this novel therapeutic approach. Apart from T-VEC, there are many oncolytic viruses that have completed different phases of clinical studies. From all the clinical trials performed so far, oncolytic viruses appear to be safe at maximum feasible doses, and in most cases, the maximum tolerable doses have not been reached. While OVs have shown excellent safety profiles, their anti-tumor efficacies are modest at best. Nevertheless, for most viruses, the MTD has not been reached, and it is likely that their anti-tumor efficacies could be increased with future advancements in virus manufacturing technology. Alternatively, novel viruses with higher anti-tumor potency could be generated, which may allow researchers to achieve maximum anti-tumor benefits at doses that are feasible with the current manufacturing process. For example, our group created a chimeric poxvirus through recombination among nine poxviruses, encompassing different strains of VACV and different species of poxvirus [70]. The chimeric poxvirus (called CF33) was found to be more potent than the parental viruses in killing cancer cells in vitro. Furthermore, the CF33 was found to abrogate tumor growth in mice at doses much lower than the doses of other oncolytic poxviruses reported in the literature [70-72]. We are currently in the process of obtaining regulatory approvals to initiate a Phase I trial with this virus.

Most of clinical trials, including those for T-VEC, have used intratumoral route for virus administration. The reason for using intratumoral administration is to avoid virus neutralization by antibodies and virus sequestration by macrophages, which could severely impede OVs, especially during repeated injections. The downside of the intratumoral route for virus injection is that the virus could not be administered in tumors that are inaccessible for direct injections. Furthermore, once a cancer has been metastasized, it is not possible to find all the metastatic nodules and inject them. While some studies have shown that injection of virus in one tumor can lead to regression of distant un-injected tumors, this phenomenon of abscopal effect has been observed only in small subset of patients. Recently, some clinical studies have used the systemic route for the delivery of oncolytic viruses, showing the feasibility of systemic injections of OVs in patients. The anti-tumor efficacy achieved through systemic injections of viruses has been modest, just as is the case for intratumoral injections of OVs.

Cancer is a complex disease that often requires a complex treatment comprising a combination of several therapeutic approaches. Results from clinical trials suggest that oncolytic viruses as monotherapy are less likely to achieve optimum therapeutic benefits. However, oncolytic viruses appear to be good candidates for combination with other therapeutic approaches, especially immunotherapy. Oncolytic viruses have been shown to subvert immune-suppressive microenvironments in tumors, making them conducive for the effectiveness of immunotherapeutics (reviewed in [73]). A number of preclinical studies have shown the effective combination of oncolytic viruses with immunotherapeutics. Consequently, recent clinical trials with oncolytic viruses have been heavily focused on the combination of viruses with immunotherapeutics, especially with immune checkpoint inhibitors. While it is too early to conclude if the impressive results from preclinical studies combining oncolytic viruses with immunotherapeutics could be translated in the clinical studies, there are some indications that the combination will work in clinic. Ribas et al. reported the results of a Phase $\mathrm{Ib}$ trial combining T-VEC with pembrolizumab (anti-PD-1 antibody) in patients with metastatic melanoma [15]. The overall response rate $(62 \%)$ and complete response rate $(33 \%)$ achieved by the combination treatment were almost double the ORR (31.5\%) and CR (16.9\%) achieved by T-VEC alone in the OPTIM (Phase III) trial. Results from other clinical studies combining oncolytic viruses with immunotherapeutics are expected to be published soon.

In summary, the field of oncolytic virotherapy has made dramatic strides in the last two decades, culminating in the approval of the first OV in the Western world. With 
many oncolytic viruses having completed Phase II trials, it is likely that more oncolytic viruses, perhaps in combination with immunotherapeutics, will soon receive approval from regulatory agencies for the treatment of different malignancies.

Funding: This research received no external funding.

Acknowledgments: The authors would like to thank Supriya Deshpande for assistance with the figure. Shyambabu Chaurasiya and Susanne G. Warner are supported through the generosity of the Natalie \& David Roberts Family. These authors wish to thank them for their philanthropy.

Conflicts of Interest: Y.F. receives royalties from Merck and from Imugene Limited. S.C. and S.G.W. declare no conflict of Interest.

\section{References}

1. Mahoney, D.J.; Stojdl, D.F.; Laird, G. Virus therapy for cancer. Sci. Am. 2014, 311, 54-59. [CrossRef]

2. Fukuhara, H.; Ino, Y.; Todo, T. Oncolytic virus therapy: A new era of cancer treatment at dawn. Cancer Sci. 2016, 107, 1373-1379. [CrossRef]

3. Vaha-Koskela, M.J.; Heikkila, J.E.; Hinkkanen, A.E. Oncolytic viruses in cancer therapy. Cancer Lett. 2007, 254, 178-216. [CrossRef]

4. Roizman, B. The function of herpes simplex virus genes: A primer for genetic engineering of novel vectors. Proc. Natl. Acad. Sci. USA 1996, 93, 11307-11312. [CrossRef]

5. Koch, M.S.; Lawler, S.E.; Chiocca, E.A. HSV-1 Oncolytic Viruses from Bench to Bedside: An Overview of Current Clinical Trials. Cancers 2020, 12, 3514. [CrossRef]

6. Rehman, H.; Silk, A.W.; Kane, M.P.; Kaufman, H.L. Into the clinic: Talimogene laherparepvec (T-VEC), a first-in-class intratumoral oncolytic viral therapy. J. Immunother. Cancer 2016, 4, 53. [CrossRef] [PubMed]

7. Kohlhapp, F.J.; Kaufman, H.L. Molecular Pathways: Mechanism of Action for Talimogene Laherparepvec, a New Oncolytic Virus Immunotherapy. Clin. Cancer Res. 2016, 22, 1048-1054. [CrossRef] [PubMed]

8. Toda, M.; Martuza, R.L.; Rabkin, S.D. Tumor growth inhibition by intratumoral inoculation of defective herpes simplex virus vectors expressing granulocyte-macrophage colony-stimulating factor. Mol. Ther. 2000, 2, 324-329. [CrossRef] [PubMed]

9. Liu, B.L.; Robinson, M.; Han, Z.Q.; Branston, R.H.; English, C.; Reay, P.; McGrath, Y.; Thomas, S.K.; Thornton, M.; Bullock, P.; et al. ICP34.5 deleted herpes simplex virus with enhanced oncolytic, immune stimulating, and anti-tumour properties. Gene Ther. 2003, 10, 292-303. [CrossRef] [PubMed]

10. Hu, J.C.; Coffin, R.S.; Davis, C.J.; Graham, N.J.; Groves, N.; Guest, P.J.; Harrington, K.J.; James, N.D.; Love, C.A.; McNeish, I.; et al. A phase I study of OncoVEXGM-CSF, a second-generation oncolytic herpes simplex virus expressing granulocyte macrophage colony-stimulating factor. Clin. Cancer Res. 2006, 12, 6737-6747. [CrossRef]

11. Senzer, N.N.; Kaufman, H.L.; Amatruda, T.; Nemunaitis, M.; Reid, T.; Daniels, G.; Gonzalez, R.; Glaspy, J.; Whitman, E.; Harrington, K.; et al. Phase II clinical trial of a granulocyte-macrophage colony-stimulating factor-encoding, second-generation oncolytic herpesvirus in patients with unresectable metastatic melanoma. J. Clin. Oncol. 2009, 27, 5763-5771. [CrossRef]

12. Harrington, K.J.; Andtbacka, R.H.; Collichio, F.; Downey, G.; Chen, L.; Szabo, Z.; Kaufman, H.L. Efficacy and safety of talimogene laherparepvec versus granulocyte-macrophage colony-stimulating factor in patients with stage IIIB/C and IVM1a melanoma: Subanalysis of the Phase III OPTiM trial. Onco Targets Ther. 2016, 9, 7081-7093. [CrossRef]

13. Andtbacka, R.H.I.; Collichio, F.; Harrington, K.J.; Middleton, M.R.; Downey, G. hrling, K.; Kaufman, HL Final analyses of OPTiM: A randomized phase III trial of talimogene laherparepvec versus granulocyte-macrophage colony-stimulating factor in unresectable stage III-IV melanoma. J. Immunother. Cancer 2019, 7, 145. [CrossRef]

14. Puzanov, I.; Milhem, M.M.; Minor, D.; Hamid, O.; Li, A.; Chen, L.; Chastain, M.; Gorski, K.S.; Anderson, A.; Chou, J.; et al. Talimogene Laherparepvec in Combination With Ipilimumab in Previously Untreated, Unresectable Stage IIIB-IV Melanoma. J. Clin. Oncol. 2016, 34, 2619-2626. [CrossRef]

15. Ribas, A.; Dummer, R.; Puzanov, I.; VanderWalde, A.; Andtbacka, R.H.I.; Michielin, O.; Olszanski, A.J.; Malvehy, J.; Cebon, J.; Fernandez, E.; et al. Oncolytic Virotherapy Promotes Intratumoral T Cell Infiltration and Improves Anti-PD-1 Immunotherapy. Cell 2017, 170, 1109-1119.e10. [CrossRef] [PubMed]

16. Cinatl, J., Jr.; Michaelis, M.; Driever, P.H.; Cinatl, J.; Hrabeta, J.; Suhan, T.; Doerr, H.W.; Vogel, J.U. Multimutated herpes simplex virus g207 is a potent inhibitor of angiogenesis. Neoplasia 2004, 6, 725-735. [CrossRef] [PubMed]

17. Toda, M.; Rabkin, S.D.; Martuza, R.L. Treatment of human breast cancer in a brain metastatic model by G207, a replicationcompetent multimutated herpes simplex virus 1. Hum. Gene Ther. 1998, 9, 2177-2185. [CrossRef] [PubMed]

18. Walker, J.R.; McGeagh, K.G.; Sundaresan, P.; Jorgensen, T.J.; Rabkin, S.D.; Martuza, R.L. Local and systemic therapy of human prostate adenocarcinoma with the conditionally replicating herpes simplex virus vector G207. Hum. Gene Ther. 1999, 10, $2237-2243$. [CrossRef] [PubMed]

19. Kooby, D.A.; Carew, J.F.; Halterman, M.W.; Mack, J.E.; Bertino, J.R.; Blumgart, L.H.; Federoff, H.J.; Fong, Y. Oncolytic viral therapy for human colorectal cancer and liver metastases using a multi-mutated herpes simplex virus type-1 (G207). FASEB J. 1999, 13, 1325-1334. [CrossRef] 
20. Coukos, G.; Makrigiannakis, A.; Montas, S.; Kaiser, L.R.; Toyozumi, T.; Benjamin, I.; Albelda, S.M.; Rubin, S.C.; Molnar-Kimber, K.L. Multi-attenuated herpes simplex virus-1 mutant G207 exerts cytotoxicity against epithelial ovarian cancer but not normal mesothelium and is suitable for intraperitoneal oncolytic therapy. Cancer Gene Ther. 2000, 7, 275-283. [CrossRef]

21. Chahlavi, A.; Todo, T.; Martuza, R.L.; Rabkin, S.D. Replication-competent herpes simplex virus vector G207 and cisplatin combination therapy for head and neck squamous cell carcinoma. Neoplasia 1999, 1, 162-169. [CrossRef]

22. Todo, T.; Martuza, R.L.; Rabkin, S.D.; Johnson, P.A. Oncolytic herpes simplex virus vector with enhanced MHC class I presentation and tumor cell killing. Proc. Natl. Acad. Sci. USA 2001, 98, 6396-6401. [CrossRef]

23. Markert, J.M.; Medlock, M.D.; Rabkin, S.D.; Gillespie, G.Y.; Todo, T.; Hunter, W.D.; Palmer, C.A.; Feigenbaum, F.; Tornatore, C.; Tufaro, F.; et al. Conditionally replicating herpes simplex virus mutant, G207 for the treatment of malignant glioma: Results of a phase I trial. Gene Ther. 2000, 7, 867-874. [CrossRef] [PubMed]

24. Markert, J.M.; Razdan, S.N.; Kuo, H.C.; Cantor, A.; Knoll, A.; Karrasch, M.; Nabors, L.B.; Markiewicz, M.; Agee, B.S.; Coleman, J.M.; et al. A phase 1 trial of oncolytic HSV-1, G207, given in combination with radiation for recurrent GBM demonstrates safety and radiographic responses. Mol. Ther. 2014, 22, 1048-1055. [CrossRef] [PubMed]

25. Todo, T. Results of Phase II Clinical Trial of Oncolytic Herpes Virus G47D in patients with Glioblastoma. Neuro-Oncology 2019, 21 (Suppl. 6), vi4. [CrossRef]

26. Edward, M.; Kennedy, T.F.; Behera, P.; Colthart, A.; Goshert, C.; Jacques, J.; Grant, K.; Grzesik, P.; Lerr, J.; Salta, L.V.; et al. Design of ONCR-177 base vector, a next generation oncolytic herpes simplex virus type-1, optimized for robust oncolysis, transgene expression and tumor-selective replication [abstract]. Cancer Res. 2019, 79 (Suppl. 13), 1455.

27. Kennedy, E.M.; Farkaly, T.; Grzesik, P.; Lee, J.; Denslow, A.; Hewett, J.; Bryant, J.; Behara, P.; Goshert, C.; Wambua, D.; et al. Design of an Interferon-Resistant Oncolytic HSV-1 Incorporating Redundant Safety Modalities for Improved Tolerability. Mol. Ther. Oncolytics 2020, 18, 476-490. [CrossRef]

28. Moss, B. Poxvirus DNA replication. Cold Spring Harb. Perspect. Biol. 2013, 5. [CrossRef]

29. Kim, J.H.; Oh, J.Y.; Park, B.H.; Lee, D.E.; Kim, J.S.; Park, H.E.; Roh, M.S.; Je, J.E.; Yoon, J.H.; Thorne, S.H.; et al. Systemic armed oncolytic and immunologic therapy for cancer with JX-594, a targeted poxvirus expressing GM-CSF. Mol. Ther. 2006, 14, 361-370. [CrossRef] [PubMed]

30. Mastrangelo, M.J.; Maguire, H.C., Jr.; Eisenlohr, L.C.; Laughlin, C.E.; Monken, C.E.; McCue, P.A.; Kovatich, A.J.; Lattime, E.C. Intratumoral recombinant GM-CSF-encoding virus as gene therapy in patients with cutaneous melanoma. Cancer Gene Ther. 1999, 6, 409-422. [CrossRef]

31. Park, B.H.; Hwang, T.; Liu, T.C.; Sze, D.Y.; Kim, J.S.; Kwon, H.C.; Oh, S.Y.; Han, S.Y.; Yoon, J.H.; Hong, S.H.; et al. Use of a targeted oncolytic poxvirus, JX-594, in patients with refractory primary or metastatic liver cancer: A phase I trial. Lancet Oncol. 2008, 9 , 533-542. [CrossRef]

32. Liu, T.C.; Hwang, T.; Park, B.H.; Bell, J.; Kirn, D.H. The targeted oncolytic poxvirus JX-594 demonstrates antitumoral, antivascular, and anti-HBV activities in patients with hepatocellular carcinoma. Mol. Ther. 2008, 16, 1637-1642. [CrossRef] [PubMed]

33. Heo, J.; Breitbach, C.J.; Moon, A.; Kim, C.W.; Patt, R.; Kim, M.K.; Lee, Y.K.; Oh, S.Y.; Woo, H.Y.; Parato, K.; et al. Sequential therapy with JX-594, a targeted oncolytic poxvirus, followed by sorafenib in hepatocellular carcinoma: Preclinical and clinical demonstration of combination efficacy. Mol. Ther. 2011, 19, 1170-1179. [CrossRef] [PubMed]

34. Breitbach, C.J.; Burke, J.; Jonker, D.; Stephenson, J.; Haas, A.R.; Chow, L.Q.; Nieva, J.; Hwang, T.H.; Moon, A.; Patt, R.; et al. Intravenous delivery of a multi-mechanistic cancer-targeted oncolytic poxvirus in humans. Nature 2011, 477, 99-102. [CrossRef]

35. Heo, J.; Reid, T.; Ruo, L.; Breitbach, C.J.; Rose, S.; Bloomston, M.; Cho, M.; Lim, H.Y.; Chung, H.C.; Kim, C.W.; et al. Randomized dose-finding clinical trial of oncolytic immunotherapeutic vaccinia JX-594 in liver cancer. Nat. Med. 2013, 19, 329-336. [CrossRef] [PubMed]

36. Moehler, M.; Heo, J.; Lee, H.C.; Tak, W.Y.; Chao, Y.; Paik, S.W.; Yim, H.J.; Byun, K.S.; Baron, A.; Ungerechts, G.; et al. Vaccinia-based oncolytic immunotherapy Pexastimogene Devacirepvec in patients with advanced hepatocellular carcinoma after sorafenib failure: A randomized multicenter Phase IIb trial (TRAVERSE). Oncoimmunology 2019, 8, 1615817. [CrossRef]

37. Kelly, K.J.; Woo, Y.; Brader, P.; Yu, Z.; Riedl, C.; Lin, S.F.; Chen, N.; Yu, Y.A.; Rusch, V.W.; Szalay, A.A.; et al. Novel oncolytic agent GLV-1h68 is effective against malignant pleural mesothelioma. Hum. Gene Ther. 2008, 19, 774-782. [CrossRef]

38. Ehrig, K.; Kilinc, M.O.; Chen, N.G.; Stritzker, J.; Buckel, L.; Zhang, Q.; Szalay, A.A. Growth inhibition of different human colorectal cancer xenografts after a single intravenous injection of oncolytic vaccinia virus GLV-1h68. J. Transl. Med. 2013, 11, 79. [CrossRef] [PubMed]

39. Gholami, S.; Chen, C.H.; Belin, L.J.; Lou, E.; Fujisawa, S.; Antonacci, C.; Carew, A.; Chen, N.G.; De Brot, M.; Zanzonico, P.B.; et al. Vaccinia virus GLV-1h153 is a novel agent for detection and effective local control of positive surgical margins for breast cancer. Breast Cancer Res. 2013, 15, R26. [CrossRef] [PubMed]

40. Haddad, D.; Zanzonico, P.B.; Carlin, S.; Chen, C.H.; Chen, N.G.; Zhang, Q.; Yu, Y.A.; Longo, V.; Mojica, K.; Aguilar, R.J.; et al. A vaccinia virus encoding the human sodium iodide symporter facilitates long-term image monitoring of virotherapy and targeted radiotherapy of pancreatic cancer. J. Nucl. Med. 2012, 53, 1933-1942. [CrossRef]

41. Donat, U.; Weibel, S.; Hess, M.; Stritzker, J.; Hartl, B.; Sturm, J.B.; Chen, N.G.; Gentschev, I.; Szalay, A.A. Preferential colonization of metastases by oncolytic vaccinia virus strain GLV-1h68 in a human PC-3 prostate cancer model in nude mice. PLoS ONE 2012, 7, e45942. [CrossRef] 
42. Wang, H.; Chen, N.G.; Minev, B.R.; Szalay, A.A. Oncolytic vaccinia virus GLV-1h68 strain shows enhanced replication in human breast cancer stem-like cells in comparison to breast cancer cells. J. Transl. Med. 2012, 10, 167. [CrossRef]

43. Zeh, H.J.; Downs-Canner, S.; McCart, J.A.; Guo, Z.S.; Rao, U.N.; Ramalingam, L.; Thorne, S.H.; Jones, H.L.; Kalinski, P.; Wieckowski, E.; et al. First-in-man study of western reserve strain oncolytic vaccinia virus: Safety, systemic spread, and antitumor activity. Mol. Ther. 2015, 23, 202-214. [CrossRef] [PubMed]

44. Thorne, S.H.; Hwang, T.H.; O'Gorman, W.E.; Bartlett, D.L.; Sei, S.; Kanji, F.; Brown, C.; Werier, J.; Cho, J.H.; Lee, D.E.; et al. Rational strain selection and engineering creates a broad-spectrum, systemically effective oncolytic poxvirus, JX-963. J. Clin. Investig. 2007, 117, 3350-3358. [CrossRef] [PubMed]

45. Parato, K.A.; Breitbach, C.J.; Le Boeuf, F.; Wang, J.; Storbeck, C.; Ilkow, C.; Diallo, J.S.; Falls, T.; Burns, J.; Garcia, V.; et al. The oncolytic poxvirus JX-594 selectively replicates in and destroys cancer cells driven by genetic pathways commonly activated in cancers. Mol. Ther. 2012, 20, 749-758. [CrossRef]

46. Downs-Canner, S.; Guo, Z.S.; Ravindranathan, R.; Breitbach, C.J.; O'Malley, M.E.; Jones, H.L.; Moon, A.; McCart, J.A.; Shuai, Y.; Zeh, H.J.; et al. Phase 1 Study of Intravenous Oncolytic Poxvirus (vvDD) in Patients with Advanced Solid Cancers. Mol. Ther. 2016, 24, 1492-1501. [CrossRef] [PubMed]

47. McConnell, M.J.; Imperiale, M.J. Biology of adenovirus and its use as a vector for gene therapy. Hum. Gene Ther. 2004, 15, 1022-1033. [CrossRef] [PubMed]

48. Garber, K. China approves world's first oncolytic virus therapy for cancer treatment. J. Natl. Cancer Inst. 2006, 98, 298-300. [CrossRef] [PubMed]

49. Fueyo, J.; Alemany, R.; Gomez-Manzano, C.; Fuller, G.N.; Khan, A.; Conrad, C.A.; Liu, T.J.; Jiang, H.; Lemoine, M.G.; Suzuki, K.; et al. Preclinical characterization of the antiglioma activity of a tropism-enhanced adenovirus targeted to the retinoblastoma pathway. J. Natl. Cancer Inst. 2003, 95, 652-660. [CrossRef]

50. Fueyo, J.; Gomez-Manzano, C.; Alemany, R.; Lee, P.S.; McDonnell, T.J.; Mitlianga, P.; Shi, Y.X.; Levin, V.A.; Yung, W.K.; Kyritsis, A.P. A mutant oncolytic adenovirus targeting the Rb pathway produces anti-glioma effect in vivo. Oncogene 2000, 19, 2-12. [CrossRef]

51. Philbrick, B.; Adamson, D.C. DNX-2401: An investigational drug for the treatment of recurrent glioblastoma. Expert Opin. Investig. Drugs 2019, 28, 1041-1049. [CrossRef] [PubMed]

52. Kuhn, I.; Harden, P.; Bauzon, M.; Chartier, C.; Nye, J.; Thorne, S.; Reid, T.; Ni, S.; Lieber, A.; Fisher, K.; et al. Directed evolution generates a novel oncolytic virus for the treatment of colon cancer. PLoS ONE 2008, 3, e2409. [CrossRef] [PubMed]

53. Machiels, J.P.; Salazar, R.; Rottey, S.; Duran, I.; Dirix, L.; Geboes, K.; Wilkinson-Blanc, C.; Pover, G.; Alvis, S.; Champion, B.; et al. A phase 1 dose escalation study of the oncolytic adenovirus enadenotucirev, administered intravenously to patients with epithelial solid tumors (EVOLVE). J. Immunother. Cancer 2019, 7, 20. [CrossRef] [PubMed]

54. Eriksson, E.; Milenova, I.; Wenthe, J.; Stahle, M.; Leja-Jarblad, J.; Ullenhag, G.; Dimberg, A.; Moreno, R.; Alemany, R.; Loskog, A. Shaping the Tumor Stroma and Sparking Immune Activation by CD40 and 4-1BB Signaling Induced by an Armed Oncolytic Virus. Clin. Cancer Res. 2017, 23, 5846-5857. [CrossRef]

55. Koski, A.; Kangasniemi, L.; Escutenaire, S.; Pesonen, S.; Cerullo, V.; Diaconu, I.; Nokisalmi, P.; Raki, M.; Rajecki, M.; Guse, K.; et al. Treatment of cancer patients with a serotype 5/3 chimeric oncolytic adenovirus expressing GMCSF. Mol. Ther. 2010, 18, 1874-1884. [CrossRef] [PubMed]

56. Ranki, T.; Pesonen, S.; Hemminki, A.; Partanen, K.; Kairemo, K.; Alanko, T.; Lundin, J.; Linder, N.; Turkki, R.; Ristimaki, A.; et al. Phase I study with ONCOS-102 for the treatment of solid tumors-An evaluation of clinical response and exploratory analyses of immune markers. J. Immunother. Cancer 2016, 4, 17. [CrossRef]

57. Maroun, J.; Munoz-Alia, M.; Ammayappan, A.; Schulze, A.; Peng, K.W.; Russell, S. Designing and building oncolytic viruses. Future Virol. 2017, 12, 193-213. [CrossRef]

58. Russell, S.J. RNA viruses as virotherapy agents. Cancer Gene Ther. 2002, 9, 961-966. [CrossRef]

59. Millward, S.; Graham, A.F. Structural studies on reovirus: Discontinuities in the genome. Proc. Natl. Acad. Sci. USA 1970, 65, 422-429. [CrossRef]

60. Phillips, M.B.; Stuart, J.D.; Rodriguez Stewart, R.M.; Berry, J.T.; Mainou, B.A.; Boehme, K.W. Current understanding of reovirus oncolysis mechanisms. Oncolytic Virother. 2018, 7, 53-63. [CrossRef]

61. Norman, K.L.; Lee, P.W. Reovirus as a novel oncolytic agent. J. Clin. Investig. 2000, 105, 1035-1038. [CrossRef]

62. Gong, J.; Mita, M.M. Activated ras signaling pathways and reovirus oncolysis: An update on the mechanism of preferential reovirus replication in cancer cells. Front. Oncol. 2014, 4, 167. [CrossRef]

63. Clements, D.; Helson, E.; Gujar, S.A.; Lee, P.W. Reovirus in cancer therapy: An evidence-based review. Oncolytic Virother. 2014, 3, 69-82. [CrossRef]

64. Morris, D.G.; Feng, X.; DiFrancesco, L.M.; Fonseca, K.; Forsyth, P.A.; Paterson, A.H.; Coffey, M.C.; Thompson, B. REO-001: A phase I trial of percutaneous intralesional administration of reovirus type 3 dearing (Reolysin(R)) in patients with advanced solid tumors. Investig. New Drugs 2013, 31, 696-706. [CrossRef] [PubMed]

65. Vidal, L.; Pandha, H.S.; Yap, T.A.; White, C.L.; Twigger, K.; Vile, R.G.; Melcher, A.; Coffey, M.; Harrington, K.J.; DeBono, J.S. A phase I study of intravenous oncolytic reovirus type 3 Dearing in patients with advanced cancer. Clin. Cancer Res. 2008, 14, 7127-7137. [CrossRef] 
66. Gollamudi, R.; Ghalib, M.H.; Desai, K.K.; Chaudhary, I.; Wong, B.; Einstein, M.; Coffey, M.; Gill, G.M.; Mettinger, K.; Mariadason, J.M.; et al. Intravenous administration of Reolysin, a live replication competent RNA virus is safe in patients with advanced solid tumors. Investig. New Drugs 2010, 28, 641-649. [CrossRef]

67. Galanis, E.; Markovic, S.N.; Suman, V.J.; Nuovo, G.J.; Vile, R.G.; Kottke, T.J.; Nevala, W.K.; Thompson, M.A.; Lewis, J.E.; Rumilla, K.M.; et al. Phase II trial of intravenous administration of Reolysin((R)) (Reovirus Serotype-3-dearing Strain) in patients with metastatic melanoma. Mol. Ther. 2012, 20, 1998-2003. [CrossRef] [PubMed]

68. Harrington, K.J.; Karapanagiotou, E.M.; Roulstone, V.; Twigger, K.R.; White, C.L.; Vidal, L.; Beirne, D.; Prestwich, R.; Newbold, K.; Ahmed, M.; et al. Two-stage phase I dose-escalation study of intratumoral reovirus type 3 dearing and palliative radiotherapy in patients with advanced cancers. Clin. Cancer Res. 2010, 16, 3067-3077. [CrossRef]

69. Lolkema, M.P.; Arkenau, H.T.; Harrington, K.; Roxburgh, P.; Morrison, R.; Roulstone, V.; Twigger, K.; Coffey, M.; Mettinger, K.; Gill, G.; et al. A phase I study of the combination of intravenous reovirus type 3 Dearing and gemcitabine in patients with advanced cancer. Clin. Cancer Res. 2011, 17, 581-588. [CrossRef] [PubMed]

70. O'Leary, M.P.; Choi, A.H.; Kim, S.I.; Chaurasiya, S.; Lu, J.; Park, A.K.; Woo, Y.; Warner, S.G.; Fong, Y.; Chen, N.G. Novel oncolytic chimeric orthopoxvirus causes regression of pancreatic cancer xenografts and exhibits abscopal effect at a single low dose. $J$. Transl. Med. 2018, 16, 110. [CrossRef]

71. Chaurasiya, S.; Chen, N.G.; Lu, J.; Martin, N.; Shen, Y.; Kim, S.I.; Warner, S.G.; Woo, Y.; Fong, Y. A chimeric poxvirus with J2R (thymidine kinase) deletion shows safety and anti-tumor activity in lung cancer models. Cancer Gene Ther. 2020, 27, 125-135. [CrossRef] [PubMed]

72. Choi, A.H.; O’Leary, M.P.; Lu, J.; Kim, S.I.; Fong, Y.; Chen, N.G. Endogenous Akt Activity Promotes Virus Entry and Predicts Efficacy of Novel Chimeric Orthopoxvirus in Triple-Negative Breast Cancer. Mol. Ther. Oncolytics 2018, 9, 22-29. [CrossRef] [PubMed]

73. Chaurasiya, S.; Chen, N.G.; Fong, Y. Oncolytic viruses and immunity. Curr. Opin. Immunol. 2018, 51, 83-90. [CrossRef] [PubMed] 